\title{
DIE SKEIDING TUSSEN CHRISTELIKE WETENSKAP EN NIE-CHRISTELIKE WETENSKAP
}

Jan J. van der Walt

Die onontwykbare kernvraag vir die bestaan van Christelike wetenskapsbeoefening, en daarom vir die Potchefstroomse Universiteit vir Christelike Hoër Onderwys, is:

Wat maak die Christelike wetenskapsbeoefening met die Bybel?

Want by die korrekte gebruik van die Bybel skei die Christelike en nie-Christelike wetenskapsbeoefening van mekaar met 'n finaliteit wat deur geen mooi slagspreuke of „Christelike" vernis verdoesel kan word nie.

Die geloofsbelydenis in die naam van die P.U. vir C.H.O. plaas hierdie Universiteit soos 'n lig op 'n staander, soos 'n stad op 'n berg. Daarmee kom ons vanself in gedrang om deur die wêreld met valkoë dopgehou te word of ons is wat ons sê dat ons is. Christus spreek in Matt. 23 die fariseërs wat „praat en nie doen nie" met sy skerpste woorde aan. En die wêreld het nie respek vir veinsery nie. Daarom mag elke dosent en student nooit ooit verslap in waaksaamheid om die lig van die Bybel so in elke vakwetenskap te laat skyn voor die mense dat hulle die werke van God kan sien en Hom verheerlik nie.

Die P.U. vir C.H.O. mag hom dus nie daaroor vererg wanneer hy skerp dopgehou word nie, maar moet juis in hierdie buitengewone eisestelling met dankbaarheid 'n erkenning van sy unieke karakter herken. As die P.U. vir C.H.O. sy Christelike karakter sou verloor sal hy gou vergete wees en met rus gelaat word as net nog een van die baie klein universiteite in die wêreld.

Daarom is dit korrek dat die P.U. vir C.H.O. weinig krag en tyd verspil om op nydighede te reageer want ons bely hier, juis omdat ons gelowiges is, dat ons sondaars is. Die taak wat aan hierdie Universiteit volbring moet word is te heerlik en te groot om ons toegespitste aandag te laat aflei van die opdrag: uitbouing van Christelike wetenskap, dit is: Wetenskapsboefening met die Bybel.

\section{WAT IS CHRISTELIKE WETENSKAP ?}

Christelike wetenskap is die enigste gesistematiseerde kennis van die volle waarheid omdat dit die Bybel gebruik as bron en ontsluiting van waarheid. Die Christen-wetenskaplike erken tegelykertyd onomwonde dat hy in sy beperkheid en sonde nie die volledige waarheid beheers nie.

Wetenskap wat sonder die Bybel beoefen word ken ook waarhede, brokstuk-waarhede. Die brokstuk-waarhede mag hoegenaamd nie tot wetenskaplike alwetendheid verhef word nie, wat wel gebeur as teenoor die Bybel van ,die wetenskap" gepraat word.

Die reg van bestaan van Christelike wetenskap berus nie op die argument dat alle wetenskap „tog maar" van subjektiewe vooringenomenhede uitgaan nie. Hierdie argument stel heeltemal onwetenskaplik, en sonder begrip van sake, die Christelike geloof in die 
Bybel gelyk aan die subjektiewe vooringenomenheid van die ongeloof wat die Bybel verwerp. Geloof en ongeloof is nie twee gelyksoortige vooringenomenhede nie, want die Bybel staan net so objektief vas binne die werklikheid as wat enige ander deel van die werklikheid, wat wetenskaplik ondersoek word, vasstaan. Die Bybel is dáar. Om die Bybel opsy te stoot uit die vakstudie is bevooroordeelde ondersoek, tensy onomstootlik bewys word dat die Bybel 'n leuen is. Die ernstige nie-Christelike wetenskaplikes weet dit en daarom ignoreer hulle nie eenvoudigweg die Bybel nie maar hulle het reeds talryke mislukte pogings aangewend om te bewys dat die Bybel onbetroubaar is. Ongeloof is, in die woorde van Paulus in Rom. 1, om die waarheid te verruil vir die leuen, om die skepsel te dien in plaas van die Skepper aan wie die lof toekom tot in ewigheid. Moedswillig word die waarheid verwerp terwyl dit binne bereik is. Wat ' $n$ mens van God kan weet is immers binne sy bereik want God het dit deur sy Selfopenbaring binne bereik van die kenvermoë van die mens gebring. Want van die begin van die skepping af kan 'n mens uit die werke van God duidelik aflei dat sy krag ewigdurend is en dat $\mathrm{Hy}$ waarlik God is, hoewel dit dinge is wat 'n mens nie met die oog kan sien nie. (Tot sover die stellinge deur Paulus in Rom. 1).

Omdat ongeloof moedswillige verwerping van die objektiefkenbare werklikheid van die Bybel is. kan dit nooit die volle waarheid bereik nie. Christelike geloof is daarenteen nie 'n vooringenomenheid wat teenoor ,wetenskap" staan nie, want geloof in Bybelse sin is "gewisse kennis" (Kg. Sondag 7), d.w.s. om met volle sekerheid te weet wat werklikheid is (Luk. 1:4); om dit wat geken word vir waaragtige waarheid te erken. En daarom, omdat dit die volle werklikheid erken, is dit in volle sin van die woord in staat tot wetenskapsbeoefening. Die Bybel is voor die ondersoekende oë van 'n Christenwetenskaplike plantkundige net so 'n werklikheid as 'n boom, en voor die oë van 'n geoloog net so 'n werklikheid as 'n laag in die aardkors. En bevindinge op grond van die ondersoek van die Bybel is net so kontroleerbaar as bevindinge op grond van 'n laboratoriumtoets met chemiese stowwe, mits die Bybel ondersoek word na sy eie aard en dus nie biblisisties of fundamentalisties nie. Want die Bybel spreek met gesag oor sake waarvoor dit bedoel om uitspraak te doen. Die Bybel sê self binne watter blikveld dit 'n feit stel. Die feit moet dan volgens die eie bedoeling skopus en sintese van die Skrif verstaan en gebrulk word.

Die fundamentele grondslae en beginsels van die wetenskap word deur die Skepper in die Bybel oor sy skepping aan ons gegee. DIT IS KENNIS WAT HY ALLEEN BESIT EN KAN OPENBAAR

En Hy gee dit in taal en begrippe wat lesers uit alle eeue, kulture en stadiums van wetenskaplike ontwikkeling kan verstaan. Daarom diskwalifiseer ' $n$ gebrek aan wetenskaplike formules en terme van ons eie tyd nie die brulkbaarheid van die Bybel nie; selfs nie vir elke vakwetenskap nie.

Ons moet die KENNISONTSLUITING deur openbaring van die Alwetende God in die Bybel herken as kennisontsluiting wat oor 
alle grense van tyd en ruimte en kulture die mens aanspreek in sy verstand om die werklikhede waarmee die wetenskap werk te begryp as God se eie werke.

Die Bybel ontsluit ook egte vakwetenskaplike detailkennis. Dit is onnodig om die rykdom van voor-die-hand-liggende detail oor die antropologiese wetenskappe aan te toon. Die Heilige Skrif is die enigste bron waarin vir ons die kennis ontsluit word oor die basiese feite wat die menslike gedrag beheers: skepping na die beeld van God, sondeval, versoening en wedergeboorte.

Soos vir die Kategese gee die Woord ook vir die Opvoedkunde kennisontsluiting oor die kind as 'n mens ,in sonde ontvang en gebore" wat tog deur inskerping van kennis (Deut. 6:7) opvoedbaar is tot 'n lewe volgens God se wet. Verrassend is die kennisontsluiting oor besonderhede selfs vir die natuurwetenskap. Hebr. 1:1-3 en $11: 3$ openbaar dat die fisiese dinge ontstaan het uit die krag van die woord van God. Die imperiese ervaring van die mens leer hom dat die sigbare dinge uit sigbare dinge ontstaan. Maar die Heilige Gees leer ons in Hebr. 11 dat die wêreld soos dit bestaan nie uit sigbare dinge ontstaan het nie want die woord van God het dit toeberei. Hierdie toebereide wêreld dra Christus deur die woord van sy krag. Die spreke, hrêma, en die krag, dunamis, d.w.s. die Woord wat krag besit, is die energie waarmee God die wêreld daarstel en waarmee Christus dit in stand hou. Die essensie van alles wat buite God bestaan is dus die energie van God se spreke. Niks wat buite God is bestaan op homself nie, maar alles is manifestasie van God se spreke, sy krag, dunamis, energie. Dit word bevestig deur 2 Petr. $3: 6$. Dit is verder veelseggend dat die krag van God werk deur sy woord, dit is sy hrêma. Hrêma is die griekse woord wat hier telkens klem lê op God se gesproke woord d.w.s. ' $n$ woord wat energie is en iets tot stand bring. Die Heilige Gees maak die werking van God se skeppings- en onderhoudingswerk vir ons duidelik met die wyse waarop 'n woord uit 'n mens uitgaan en werk. Die hrêma, die spreke van God, het die Logos, die Persoon van die Seun van God, tot inhoud.

Dus: God skep die wêreld, Christus onderhou die wêreld deur sy energie wat van Hom uitgaan soos 'n woord die menslike mond verlaat.

Die essensie van alles wat in die wêreld bestaan is dan die energie van God. Maar die wetenskap het, na eeue van weerstand, eers onlangs vasgestel dat materie en energie ekwivalent is en dat die geheim van die fisiese atoom bindende energie is. Wat meer is: Die vakwetenskap het eers in die laaste jare vasgestel dat alle fisiese en biologiese prosesse bepaal word deur die werking van energie en entropie. Die betekenis hiervan is: geen nuwe energie ontstaan nie, en geen energie word vernietig nie, maar energie raak buite gebruik, terwyl slegs die bestaansvorm verander en kan verander. Die geskape energie word slegs onderhou. Dus die skeppingsdaad is voltooi, soos Gen. 2:1-3 sedert Moses meedeel.

Hoe belangrik die besonderhede ookal mag wees, die sintese in die kennisontsluiting van die grondslae deur die Bybel is die allerbelangrikste, want dit leer ons: God alleen skep en herskep. 
Hy het alles gemaak en Hy sal alles weer nuut maak. Hý. En daarop, sê Rom. 8, wag die skepping met reikhalsende verlange.

Wie die Bybel ignoreer, ignoreer God wat van Homself in die Bybel getuig (2 Kor. 2:1). Die „is" van God is dié werklikheid, en daarvoor ontsluit die Bybel aan ons onontbeerbare kennis. God se „Ek is" is die indikatief of werklikheid wat deur die Woord van God meegedeel word.

Daarom is die Bybel die enigste handboek deur die Alwetende Leermeester (Job $36: 22$; vgl. Ps. 139:6 en Matt. 23:10) van die allerbelangrikste, alles-bepalende en allerfinaalste kennisontsluiting: God is. Hy definieer Hom Self in Ex. 3:14: Ek is wat Ek is.

Hoe kan enige egte wetenskap die Sprekende lewende God ignoreer én terselfdertyd tot volle vakkennis van sý werk kom? Dit kan nog minder gebeur as wanneer die wiskunde die bestaan van getalle ignoreer.

En: Hy is byv. die Skepper van getal. Getal is nie die vrug van die mens se subjektiewe denke nie. Met die skepping van verskeidenheid het God getal geskep: dae, soort, mense. En getal lê ook reeds in die openbaring van die Drie-eenheid van God.

Daarom moet die Bybel voluit geintegreer word in elke vakwetenskap voordat daardie VOLUIT WETENSKAP KAN WEES DEUR GOD IN SY WERKE TE LEER KEN.

\section{WAT IS DIE UNIEKE AARD VAN CHRISTELIKE WETENSKAP ?}

Die unieke eie aard van Christelike wetenskap is dat dit die kennisontsluiting van die Bybel voluit akkommodeer. Die resultaat daarvan is:

- God word geken en eerbiedig as die Skepper, en daarom is wetenskaplike ondersoek van sy skeppingswerk 'n arbeid wat met AL die beskikbare wetenskaplike middele en metodes die werklikheid (wat Hy gemaak het) te leer ken en verstaan.

- God die Skepper is die enigste God en daarom is die werk van sy hande, die werklikheid wat deur die wetenskap ondersoek word, 'n eenheid.

- God openbaar Hom in sy skeppingswerk, en nog duideliker in sy Woord, die Bybel. Daarom bring alle egte wetenskaplike kennis die mens tot kennis van God. Om hierdie rede kan Christelike wetenskap alle egte kennis, ongeag wie dit uit die geskape werklikheid oopgedek het, akkommodeer as deel van die kennis aangaande God soos Hy Hom in sy werke bekend maak.

\section{WAT IS DAN DIE SKEIDINGSPRINSIPE TUSSEN CHRISTELIKE}

EN NIE CHRISTELIKE WETENSKAP ?

$\star$ Elkeen wat die werklikheid ondersoek sonder die Bybel kan hoogstens kom tot 'n vermoede of hipotese dat daar ' $n$ God is. Elkeen wat die Bybel as werklikheid erken in sy wetenskaplike ondersoek kan tot die resultaat kom om God wat is te ken.

$\star \quad$ Christelike wetenskap is gerig op kennis van God en nie-Christelike wetenskap is gerig op kennis van die mens en sy omgewing. 
$\star \quad$ Christelike wetenskap lei tot aanbidding van God, en nie-Christelike wetenskap lei tot handhawing van die mens in sy leefwêreld.

* Kennis van en aanbidding van God omvat as vrug, en nie as doel, kennis en handhawing van die mens in sy omgewing. Egter nie in die sin van selfverlossing nie, maar as 'n diens van dank aan God die Skepper.

\section{WAAROM PRAAT ONS DAN SO UITDRUKLIK VAN} CHRISTELIKE WETENSKAP?

1. Omdat alles deur Christus, die Logos, ontstaan het en onderhou word. (Daarop is reeds gewys).

2. Christelike wetenskap ken Christus deur die Bybel as die enigste en volkome Verlosser van mens en skepping. Daarom is dit nie daarop gerig om aan die mens pynloosheid, en onsterflikheid te gee nie. Dit soek nie 'n aardse Utopia nie. Christelike wetenskap bring die werklikhede van die Bybel in berekening en is dus gerig op dankbare diens aan God wat verlossing skenk. En die resultate van die wetenskapsbeoefening word dankbaar as seëninge erken wat nou al ons deel word van die verlossing deur Christus. Daarom word hierdie resultate aangewend as genadegawes om God en die naaste mee lief te hê. Die laserstraal is dan ' $n$ mediese instrument waarmee die ragfynste buisies vir lewewekking in die menslike liggaam oopgemaak word en nie 'n oorlogswapen om dood te maak nie.

DIE REELS VIR DIE REGTE GEBRUIK VAN DIE BYBEL IN

DIE WETENSKAPSBEOEFENING

$\star \quad$ Die eerste reël is: Die Bybel verklaar homself. Dieselfde Heilige Gees wat die Bybel laat skrywe het, verlig ook die verstand van die leser om dit te verstaan. Daarom kan elke ware gelowige die Bybel, met biddende arbeid, in sy vakwetenskap gebruik. Hy is nie onmagtig afhanklik van Teologie nie.

$\star$ Tweedens is die Bybel 'n organiese eenheid. Dit beteken dat dit nie in brokstukke en met losstaande tekste gebruik kan word nie, maar dat elke teks binne die openbaringshistoriese eenheid van die Bybel verstaan moet word. Elke gelowige moet die Bybel daarom getrou in sy geheel lees. Die sintese, die eenheid gaan vo6r die analise, die dele. Die dele moet in die lig van die geheel verstaan word, terwyl die dele die geheel bevestig. Die Bybel mag na sy eie aard nie anders as sintetiesanalities verklaar word nie. Die wetenskap toon 'n beeld van ontsaglike analisering, en bestaan uit 'n oerwoud van geanaliseerde feite: atome en selle en getalle en molekules en woorde en datums en gebeurtenisse en wette. In hierdie verwarrende veelheid van besonderhede gee alleen die Bybel samehang om die wetenskapsbeoefening deur kennisontsluiting te bring tot die eenheid van alle egte en ware kennis: Die enige God en die eenheid van sy werke.

* Daarom pas wetenskapshoogmoed nie in die patroon van die 
Christelike wetenskap nie. Elke Christen-wetenskaplike weet hy ken ten dele; en: die volle waarheid is nie 'n optelsom van soveel brokstukkies nie. Daar was nog net Een wat kon sê: „Ek is die Waarheid".

Dit is essensieel vir die wetenskap dat die eenheid van die werklikheid met Christelike ootmoed gesoek word. Christelike wetenskap is vry van atomistiese skeiding van die vakwetenskappe, want elke wetenskaplike is bewustelik besig om met almal saam een God in sy een Selfopenbaring van verskeie kante te leer ken uit een openbaring in natuur en Bybel (N.G.B. art. 2). Daarom dwing die Bybel die wetenskaplikes aan die P.U. vir C.H.O. tot spanwerk om saam die geestelike gebou van die Universiteit te ontplooi.

In die woorde van die gryse prof. Cachet by sy aftrede: Ons bou 'n tempel van die wetenskap. 'n Tempel waar die enige Here geken en aanbid word.

Rede by die gradeplegtigheid van fakulteite Teologie en Opvoedkunde, $2 / 4 / 81$. 